\title{
NAVORSING EN OPLEIDING IN DIE DEPARTEMENT
}

\section{FISIOLOGIE EN BIOCHEMIESE NAVORSING}

Die kultuuropdrag van die mens, nl. onderwerping en beheersing van die natuur, eis dat die mens deeglike en grondige kennis van die natuur moet hê. Hiervoor is nie net instandhouding van bestaande kennis noodsaaklik nie maar ook die ontwikkeling van nuwe kennis essensieel. Hieruit volg dus dat opleiding sowel as navorsing noodsaaklik is.

'n Belangrike uitgangspunt by die bestudering van die natuur is dat die gevolge van die sondeval in gedagte gehou moet word. Dit is veral ook van belang by die beskouing van die wese van siekte-toestande.

Ons glo dat die mens die kroon van die skepping van God vorm. Kennis van die struktuur en werking van die liggaam van die mens kan 'n baie belangrike deel van ons kultuur uitmaak. In die Woord van God word telkens na die menslike liggaam verwys wanneer onsienlike dinge verduidelik word, byvoorbeeld die voortreflike beskrywing van die eenheid van die liggaam in 1 Kor. $12: 12-31$, waar die eenheid van die kerk, die liggaam van Christus, uiteengesit word. Dit is 'n verstommende wonderwerk dat in die menslike liggaam 12 miljard (4 $\mathrm{x}$ die wêreldbevolking) individuele lewende eenhede (die selle van die liggaam) tot 'n harmoniese eenheid geïntegreer en gekoördineer word. Liggaam en gees vorm ook 'n eenheid en om die mens, die medemens en jouself, goed te begryp is kennis van die werking van die liggaam noodsaaklik. Die enigste oplossing tot die ernstige gesondheidsprobleme in ons samelewing is die ontwikkeling van meer kennis oor die probleme. Om 'n gesonde leefwyse te kan ontwikkel en 'n algemene samelewingspatroon te kan skep waarin meeste mense redelik gelukkig kan werk, is onder andere kennis van die werking van die liggaam vir werknemers sowel as werkgewers, in alle fasette van die samelewing, noodsaaklik.

Die ontwikkeling in die vak Fisiologie toon duidelik aan dat die vak nie net 'n dienskneg van die mediese wetenskap is nie, maar die karakter van 'n basiese biologiese vakwetenskap het. Die sg. lewenswetenskappe lê al meer klem op die meganismes van lewensprosesse soos dit by die soogdier en die mens bestaan. Volgens 'n opname wat in die Verenigde State van Amerika gemaak is gedurende 1967, was daar, by 
die mediese skole, $70 \%$ personeellede werksaam wat nie kliniese mediese kwalifikasies gehad het nie, maar wel opleiding in die basiese biologiese en chemies-fisiese wetenskappe ontvang het. Dit toon die belangrike rol wat ' $n$ basiese benadering tot die biologie van die mens in die V.S.A. speel

In die Departement Fisiologie en Biochemiese Navorsing is die belangrikste uitgangspunt dat 'n fundamentele studie van die basiese lewensverskynsels soos dit by die soogdier en die mens voorkom, onderneem moet word. Hierdie basiese verskynsels sluit lewenskenmerke in soos 1) prikkelbaarheid, 2) geleidingsvermoë, 3) outomasie (d.i. sogenaamde spontane ontstaan van aktiwiteit, bv. in die hart en senuweesisteem), 4) ritmisiteit, 5) energie-transformering (d.i. verandering van energie bv. voedselenergie word verander na meganiese beweging (spiersametrekking), elektriese verskynsels of sintese van ingewikkelde chemiese molekules, selstrukture (organelle), selle en weefsels, bv. eiwitsintese).

In die Departement word hierdie verskynsels bestudeer met behulp van tegnieke en denkmetodes van die chemie, fisika en wiskunde. Daarom was die benoeming van beide 'n biochemikus en biofisikus in die Departement 'n noodsaaklike en wyse stap wat deur die Raad van die P.U. vir C.H.O. geneem is.

Dit is egter nie voldoende om net 'n analitiese studie van lewensverskynsels te maak nie. Daarom word die studie van die eenheid van lewende organismes as sentrale en rigtinggewende teorie beskou. Die studie van die wyse waarop die funksies van die selstrukture (organelle), die verskillende selle, weefsels, organe en sisteme van die liggaam geîntegreer en gekoördineer word tot 'n harmoniese eenheid, vorm 'n sentrale tema in die opleiding asook 'n rigtinggewende hipotese in die navorsingswerk van die Departement Fisiologie en Biochemiese Navorsing aan die P.U. vir C.H.O. Hiervan vorm kennis en studie van die beheer- of reguleringsprosesse in die liggaam weer die belangrikste komponent. 'n Oorsig oor die waarde, geskiedenis, aard en toekoms van die studie van fisiologiese beheermeganismes is tevore reeds gepubliseer. ${ }^{1}$ Daar is aangetoon hoedat groot leemtes bestaan in die huidige kennis van die beheer van belangrike prosesse in die liggaam. Meer navorsing behoort dringend uitgevoer te word oor o.a. die

1 P. J. Pretorius: Die menslike liggaam as fisiologiese eenheid. Koers XXXVI, bl. 21-51, 1968. 
beheer van die sametrekkingskrag en dinamiese funksies van die hart.

Kennis van die beheerprosesse van die natuur stel die mens daartoe in staat om beheer oor die natuur uit te oefen. 'n Dringende behoefte in dié verband in die Republiek van S.A. is ook die stigting van 'n Instituut vir brein- en senuweenavorsing.

Die verlede het bewys dat 'n drang om voordeel te put uit toegepaste navorsing wat op kort termyn oplossings vir aktuele probleme moet oplewer, maklik lei tot die doodloopspoor van wetenskaplike oppervlakkigheid. Ons moet leer uit die verlede, ons moet die goeie behou en daarop bou. Die bruikbaarste en waardevolste ontdekkings van die verlede was juis die produk van sogenaamde basiese navorsing en nie van navorsingsprogramme wat gerig was op 'n definitiewe toepassing nie. Daarom moet die vak Fisiologie selfs in 'n mediese skool nie as toegepaste vak beoefen word nie maar as basiese biologiese wetenskap. Daar is egter 'n wisselwerking tussen die wetenskap en die toepassings van die kennis. As siektes van lewende organismes beskou word as afwykings van die normale funksie en struktuur of as 'n natuurlike eksperiment, dan is dit duidelik dat ' $n$ studie van die normale van belang is om siekte te begryp, maar dat 'n studie van siektes ook van belang kan wees om sekere gegewens oor die normale funksies te verkry.

Daarom word aspekte van sekere siektetoestande wat ernstige probleme in ons samelewing vorm ook in die Departement Fisiologie en Biochemiese Navorsing ondersoek. Die navorsingswerk kan dus in twee groepe verdeel word, naamlik basiese navorsing en toegepaste navorsing.

\section{Basiese navorsing}

a) Metodes om hartwerking te bestudeer: Daar bestaan 'n groot behoefte aan beter metodes om meer basiese inligting in te win oor die normale funksionering van die hart en bloedsomloop. Weinig is bekend van die aspekte van hartfunksies wat verband hou met bloedvloei, vloeisnelheid en vloeiversnelling. Hierdie aspekte kan beskou word as die hoër-dinamiese funksies van die hart. Bloedvloei word direk gemeet by proefdiere en met behulp van analoë-rekenaar-eenhede verwerk sodat die hoër dinamiese funksies verkry word.

Metodes word ook ontwikkel om met indirekte metings 
soortgelyke gegewens by die mens te verkry. Die waarde van bestaande en nuwe metodes om indirekte metings van die hoër dinamiese funksies te maak word met behulp van proefdiere ondersoek.

b) Bio-elektriese verskynsels: Alle lewende sisteme vertoon elektriese verskynsels. Elektriese verskynsels wat by die mens gemeet kan word soos die elektrokardiogram (hart), elektro-ensefalogram (brein), elektromiogram (spiere), elektroretinogram (oog) ens. is op hierdie fisiologiese verskynsel gebaseer. Die Departement Fisiologie beskik oor die modernste toerusting in die Republiek om elektriese verskynsels op sellulêre vlak te bestudeer. Die ontstaan en geleiding van die hartimpuls word bestudeer. Die ontstaan van hierdie elektriese verskynsels wat in lewende selle voorkom, kan verklaar word a.g.v. sekere basiese eienskappe van die selmembraan. Glas mikro-elektrodes met 'n punt van ongeveer een tienduisendste van 'n millimeter word in die lewende selle van verskillende strukture van die hart geplaas en die membraan- en aksiepotensiale word gemeet en gefotografeer.

c) Biochemiese navorsing: Vir die instandhouding van enige lewende sisteem en vir groei en herstel is sintese-prosesse noodsaaklik. In die Fisiologie Departement word navorsingswerk gedoen oor verskillende aspekte van eiwit-sintese. Om dit moontlik te maak word die noodsaaklike selbestanddele wat verantwoordelik is vir eiwit-sintese uit die selle gehaal met behulp van ultrasentrifugering. Die selkomponente is ribosome, selplasma-ensieme en transporteur-ribonukleïensure. Aan hierdie selkomponente kan nou „voorgeskryf” word om eiwitte uit aminosure te vorm. Die aminosure word met radioaktiewe atome „gemerk" om die sintese-proses na te gaan. Sintetiese poliribonukleotiede of natuurlike boodskapper ribonukleīensure word gebruik om aan die geisoleerde selkomponente voor te skryf watter eiwitsintese-program uitgevoer moet word. Verder word ook die sub-eenhede van die ribosome geïsoleer om na te gaan watter rol dit speel by die inisiëring van eiwitsintese.

Tydens siektetoestande van die hart tree soms abnormale toename of afname van die hartspier-eiwitte in. (Hipertrofie of atrofie). Eiwitsintese-studies van die hartspier word uitgevoer en toegepas om ondersoek in te stel na die meganisme van een tipe hartversaking.

d) Fisiko-chemiese aspekte: Daar bestaan 'n geweldige leemte tussen die kennis van biofisiese en biochemiese lewens- 
verskynsels. So is byvoorbeeld weinig bekend van die belangrike skakels wat moet bestaan tussen die elektriese verskynsels by lewende selle en die uiteindelike fisiologiese funksie, soos sametrekking van 'n spier. Hierdie proses staan by spiere bekend as die prikkel-sametrekkingsmeganisme. Een van die dosente van die Departement het onlangs met behulp van 'n Internasionale na-doktorale beurs opleiding in die V.S.A. ontvang sodat navorsing op hierdie belangrike gebied gedoen kan word. Veral vir die fisiologie van die hart is hierdie terrein van groot belang.

\section{Toegepaste navorsing}

Die Instituut vir Fisiologiese en Biochemiese Navorsing het tot dusver veral navorsing onderneem ten opsigte van afwykings van die hart en bloedsomloop.

Koronêre hartsiektes vorm een van die ernstigste gesondheidsprobleme in ons samelewing. 'n Aantal aspekte van die probleem word ondersoek. Die rol wat dieetfaktore speel word met behulp van proefdiere ondersoek. Eksperimentele nabootsing van die siekte is noodsaaklik om 'n model vir verdere eksperimentering te verkry. Konyne word gebruik. Aterosklerose word met behulp van 'n aterogeniese dieet opgewek en die fisiologiese veranderinge word bestudeer. Biochemiese sowel as kardiografiese metings word gelyktydig toegepas. In hierdie opsig word unieke werk verrig omdat weinig ander laboratoria ter wêreld hierdie verskynsels gelyktydig ondersoek. Verder is reeds ook die rol van faktore soos senuweespanning (outonome wanbalans) en oefening ondersoek.

Hartversaking as gevolg van versteuring van die hartspiersametrekkingsmeganisme word bestudeer. 'n Eksperimentele model van hartversaking word verkry met proefdiere soos bokke en skape waarby gousiekte m.b.v. die gousiekteplant opgewek word. Elektrokardiogramme, hartgeluide, bloeddruk en hoër-dinamiese hartfunksies word bestudeer ten einde meer te wete te kom van die prosesse tydens hartversaking.

Versteuring van die sametrekkingsproses en eiwitsintese by die hart tydens hartversaking word m.b.v. biochemiese tegnieke bestudeer.

Versteuring van die ritme en geleiding in die hart word bestudeer. Eksperimenteel word ritme-versteurings by proefdiere opgewek m.b.v. stowwe soos hartgifglikosiede. Tulpgif word o.a. ook gebruik. Behalwe bogenoemde tegnieke word 
ook mikro-elektrodes gebruik om die ritme en geleidingversteurings op sellulêre vlak te bestudeer.

Nuwe hartgeneesmiddels wat deur farmaseutiese firmas ontwikkel word, word in samewerking met die Departement Farmakologie ondersoek. Verskillende voordragte oor al die bg. navorsingswerk is reeds deur personeel van die Departement voor nasionale en internasionale vakkongresse gelewer. Die navorsingsresultate het verskyn in verskillende internasionale tydskrifte, kongresverslae, en dele van die werk is reeds in standaard vak-handboeke opgeneem.

Verskillende doktorsgraadstudente en meestersgraadstudente het reeds hul proefskrifte en verhandelings hier voltooi of is tans daarmee besig. Verskillende belangrike betrekkings in die land word deur oudstudente van die Departement beklee.

Al die dosente wat leiding gee in bogenoemde navorsing, het in internasionaal-erkende laboratoria opleiding ontvang en het self reeds navorsingswerk verrig wat van internasionale standaard is.

Opleiding en navorsing kan nie van mekaar geskei word nie. Navorsing is ' $n$ uitdaging, dit is stimulerend en het ' $n$ skeppingskarakter. Een van die belangrikste motiewe vir navorsing is seker die voordele wat dit vir die navorser self inhou. ' $n$ Belangrike feit is dat navorsing ' $n$ innerlike drang by die beoefenaar daarvan opwek. 'n Drang tot nuwe kennis tot beheersing van die natuur en uitoefening van sy menslike gesag. Dit wek die besef van eie nuttigheid en menswaardigheid. Navorsingswerk laat 'n meganisme by 'n individu ontwikkel waardeur hy belangstelling ontwikkel en verdere ondersoek begin instel. Die verdere ondersoek lewer nuttige kennis, en bevrediging en intellektuele ontwikkeling. 'n Meganisme van belangstelling, ondersoek, inspirasie en nuwe kennis ontwikkel as 'n progressiewe kringloop. In die proses word groot hoeveelhede reeds bestaande feite byna sonder moeite, ongemerk, opgeneem en word die opleiding van die persoon aangevul en ontwikkel hy intellektueel. Daarom kan navorsingswerk en 'n navorsingsatmosfeer as 'n kragtige opleidingsinstrument beskou word omdat hierdie belangstelling-inspirasie-kringloop daardeur ontstaan en voortdurend in stand gehou word. Saam met die ander dryfvere soos ontwikkeling van die wetenskap, openbare en naastediens en die beoefening van ' $n$ beroep, vorm die invloed van navorsing op die navorser self dus 'n selfonderhoudende, voortdurende, selfopleidende meganisme. Op die 
wyse kan die universiteit goeie studente oplei wat as volwaardige landsburgers hul plek kan volstaan.

Hiervoor is nie groot navorsingsprogramme nodig nie maar wel deeglik opgeleide bekwame en geïnspireerde dosent-navorsers wat beskik oor die nodige fasiliteite. Daar bestaan alle hoop dat hierdie ideaal ook in die Departement Fisiologie en Biochemiese Navorsing verder verwesenlik sal word.

P.U. vir C.H.O.

P. J. Pretorius. 